\title{
Analisis Kesulitan dalam Menyelesaikan Soal Materi Operasi Bilangan Cacah Siswa Sekolah Dasar
}

\author{
Gita Ayu Nengsih ${ }^{\left.1^{*}\right)}$ \& Heni Pujiastuti ${ }^{2}$ \\ ${ }^{1,2}$ Universitas Sultan Ageng Tirtayasa, Serang, Indonesia
}

\begin{tabular}{l} 
INFO ARTICLES \\
Article History: \\
Received: $17-06-2021$ \\
Revised: $29-06-2021$ \\
Approved: $30-06-2021$ \\
Publish Online: $30-06-2021$ \\
\hline
\end{tabular}

Key Words:

Difficulty Analysis; Whole Number Operation; Elementary School Students;

This article is licensed under a Creative Commons AttributionShareAlike 4.0 International License.

\begin{abstract}
This study aims to determine the difficulties of students in working on problems on whole number operations. The type of research used is descriptive qualitative. The subjects studied were grade 3 students of SDIT ALHUSNA Serang City as many as 7 students based on the results of daily tests which were below the KKM. Data collection techniques used are tests and interviews. The test instrument given was 5 essay questions in the form of story questions. The results showed that the causes of the difficulties experienced by students in solving whole number operations were: 1) difficulties in using mathematical arithmetic operations; 2) difficulty in understanding the intended question and difficulty in translating it into mathematical sentences; 3) difficulty in solving problems related to whole number arithmetic operations (addition, subtraction, multiplication, and division). This is as from the results of the analysis it is known that the highest percentage of students' difficulties in performing arithmetic operations reaches $71 \%$.
\end{abstract}

\begin{abstract}
Abstrak: Penelitian ini bertujuan untuk mengetahui kesulitan siswa dalam mengerjakan soal pada materi operasi bilangan cacah. Adapun jenis penelitian yang digunakan adalah deskriptif kualitatif. Subjek yang diteliti adalah siswa kelas 3 SDIT AL-HUSNA Kota Serang sebanyak 7 siswa berdasarkan pada hasil ulangan harian yang berada di bawah KKM. Teknik pengumpulan data yang digunakan adalah tes dan wawancara. Instrumen tes yang diberikan sebanyak 5 butir soal essay berbentuk soal cerita. Hasil penelitian menunjukkan bahwa penyebab kesulitan yang dialami siswa dalam menyelesaikan soal operasi bilangan cacah diantaranya: 1) kesulitan dalam menggunakan operasi hitung matematika; 2) kesulitan dalam memahami soal yang dimakud dan kesulitan dalam menerjemahkannya ke dalam kalimat matematika; 3) kesulitan dalam menyelesaikan soal berkaitan dengan materi operasi hitung bilangan cacah (penjumlahan, pengurangan, perkalian, dan pembagian). Hal ini sebagaimana dari hasil analisis diketahui bahwa persentase tertinggi kesulitan siswa dalam melakukan operasi hitung mencapai $71 \%$.
\end{abstract}

Correspondence Address: Jln. Syeh Nawawi Al Bantani No.76 Serang, Kota Serang, 42123, Indonesia; e-mail: gitaayunengsihg@gmail.com

How to Cite (APA $6^{\text {th }}$ Style): Nengsih, G.A., \& Pujiastuti, H. (2021). Analisis Kesulitan dalam Menyelesaikan Soal Materi Operasi Bilangan Cacah Siswa Sekolah Dasar. JKPM (Jurnal Kajian Pendidikan Matematika), 6(2): 293-306

Copyright: 2021 Gita Ayu Nengsih, Heni Pujiastuti

Competing Interests Disclosures: The authors declare that they have no significant competing financial, professional or personal interests that might have influenced the performance or presentation of the work described in this manuscript. 


\section{PENDAHULUAN}

Pendidikan merupakan hal mendasar yang dibutuhkan manusia dalam mengembangkan kemampuan yang dimilikinya. Melalui pendidikan manusia akan memperoleh pengetahuan yang dapat memberikan perubahan dalam hidup seseorang sehingga kualitas suatu bangsa akan meningkat sejalan dengan meningkatnya kualitas pendidikan. Menurut Kompri (2015) menyatakan bahwa "pendidikan merupakan usaha yang secara sadar dilakukan oleh seseorang untuk menyelesaikan latihan pengembangan diri bagi siswa agar menjadi individu sesuai dengan tujuan yang ingin dicapai sebelumnya. Perkembangan ilmu pengetahuan dan tekonologi yang begitu pesat saat ini tidak terlepas dari pendidikan yang berkualitas sehingga mampu menghasilkan sumber daya manusia yang berkualitas pula, salah satu cirinya adalah adanya kemampuan berpikir kritis. Matematika merupakan salah satu mata pelajaran yang dapat mempersiapkan siswa untuk berpikir kritis. Matematika diajarkan pada setiap jenjang pendidikan mulai dari sekolah dasar hingga tahap perguruan tinggi. Hal ini dilakukan agar dapat menciptakan manusia yang memiliki kemampuan berpikir kritis, logis, sistematis, analitis, dan kreatif, serta kemampuan dalam berkolaborasi (Depdiknas, 2006).

Salah satu tujuan pembelajaran matematika di sekolah dasar adalah agar peserta didik dapat memahami konsep, menjelaskan hubungan antar konsep, mengaplikasikan konsep atau prosedur pemecahan masalah secara tepat, luwes, akurat, dan efisien serta dapat menyelesaikan masalah matematis pada tingkat kesulitan tertentu dengan baik dan benar. Penguasaan pelajaran matematika sangat penting bagi siswa sekolah dasar (Widyastuti \& Pujiastuti, 2014). Menurut Permendiknas Nomor 22 Tahun 2006 mengenai Standar isi pada satuan pendidikan SD/MI, mata pelajaran matematika terdiri dari tiga aspek yaitu: bilangan, geometri dan pengukuran, serta pengolahan data. Salah satu cakupan bilangan adalah operasi bilangan bulat meliputi penjumlahan, pengurangan, perkalian, dan pembagian. Materi operasi bilangan cacah merupakan materi dasar yang seharusnya dapat dikuasai oleh peserta didik karena menjadi modal awal untuk mempelajari matematika yang lebih kompleks di jenjang selanjutnya. Meskipun pemahaman konsep operasi hitung penting untuk dimiliki siswa, namun faktanya siswa banyak mengalami kesulitan dalam mengoperasikan bilangan bulat. Berdasarkan penelitian, yang dilakukan oleh Imelda, Yusmin, \& Suratman (2014); Utami (2016) dalam penelitiannya menyebutkan bahwa siswa masih mengalami kesulitan dalam menyelesaikan operasi hitung campuran pada bilangan bulat.

Berdasarkan hasil wawancara dengan Guru Kelas III SDIT AL-HUSNA, diperoleh informasi bahwa siswa kelas III masih mengalami kesulitan dalam belajar matematika terutama dalam menyelesaikan soal operasi bilangan cacah. Menurut Subini dalam (Haryadi \& Nurmaningsih, 2019) menyatakan bahwa kesulitan belajar adalah kondisi yang memperlihatkan ciri-ciri hambatan dalam kegiatan untuk mencapai tujuan sehingga diperlukan usaha untuk mengatasi gangguan tersebut. Kesulitan yang dialami oleh siswa dalam menyelesaikan soal operasi bilangan cacah terjadi karena kurangnya pemahaman siswa mengenai konsep-konsep yang berkaitan dengan operasi bilangan cacah dan rendahnya kemampuan siswa dalam berhitung. Di dalam pembelajaran matematika, penguasaan konsep merupakan hal yang penting (Arnidha, 2015). Dengan penguasaan konsep yang dimiliki maka siswa dapat dengan mudah menyelesaikan permasalahan yang berkaitan dengan operasi bilangan cacah dalam kehidupan sehari-hari, mulai dari di sekolah, di rumah, maupun di lingkungan masyarakat Kesulitan yang dialami oleh siswa dapat terjadi oleh beberapa faktor, baik faktor internal yang berasal dari dalam diri siswa maupun faktor eksternal yang berasal dari luar diri siswa. Menurut Djamarah (2015:246) ciri-ciri kesulitan belajar diantaranya: 1) Siswa menunjukan prestasi belajar yang rendah; 2) Hasil belajar yang dicapai tidak sepadan dengan usaha yang dilakukan; 3) Siswa lambat dalam mengerjakan tugas-tugasnya; 4) Siswa menunjukan sikap yang kurang wajar, seperti acuh tak acuh, mudah tersinggung, dan sebagainya; 5) Siswa menunjukan tingkah laku yang tidak seperti biasanya ditunjukan kepada orang lain; 6) Siswa yang memiliki IQ tinggi, seharusnya 
mendapatkan hasil belajar yang tinggi namun hasil belajar yang didapat tergolong rendah; 7) Peserta didik yang mendapatkan prestasi belajar yang tinggi pada sebagian mata pelajaran, namun dilain kesempatan prestasi belajarnya menurun drastis. Pada umumnya siswa mengalami kesulitan dalam belajar matematika karena mereka menganggap bahwa pelajaran ini sulit dimengerti dan dipahami terlebih dihadapkan oleh angka-angka dan simbol-simbol yang begitu banyak. Sejalan dengan hasil penelitian yang dilakukan Imawati \& Dharma (2016), hasilnya menunjukkan bahwa kesulitan yang dialami siswa ialah kesulitan dalam menggunakan rumus, kesulitan dalam menghitung desimal, dan kesulitan dari dalam diri siswa. Selain itu guru biasanya menyajikan pembelajaran yang kurang menarik sehingga terkesan membosankan. Metode ceramah merupakan metode yang sering diterapkan guru di sekolah dalam pelaksanaan belajar dan guru kurang mampu mengelola pembelajaran yang tepat untuk memotivasi siswa terlibat aktif dalam pembelajaran. Menurut Rubai et. al. (2015), cara mengatasi kesulitan belajar matematika adalah: 1) Mengubah pola pikir siswa; 2) Menciptakan model pembelajaran tutor sebaya; 3) Pendekatan kepada siswa baik secara individu maupun menyeluruh; 4) memberikan motivasi; 5) memberikan soal-soal latihan.

Dalam pembelajaran guru perlu memahami perbedaan siswa secara individu, dan sebaiknya memberikan pelayanan pembelajaran sesuai dengan perbedaan siswa tersebut. Siswa akan berkembang sesuai dengan kemampuannya masing-masing. Perbedaan yang dimiliki oleh setiap individu ini nantinya akan berpengaruh terhadap cara dan hasil belajar siswa. Perbaikan pembelajaran perlu diupayakan untuk menyelesaikan permasalahan kesulitan belajar siswa. Tidak sedikit guru yang mengeluh mendapatkan siswa-siswinya yang tidak bisa memahami konsep perkalian dan pembagian bilangan asli, bahkan konsep penjumlahan dan pengurangan pun mereka tidak paham terutama yang melibatkan bilangan negatif. Dalam menyelesaikan soal berbentuk angka mungkin mereka masih bisa mengerjakan karena mengerti soal yang dimaksud, namun ketika dihadapkan soal cerita dalam bentuk kalimat, siswa kesulitan memahami soal sehingga mengakibatkan salah menerjemahkan soal kedalam kalimat matematika. Keberhasilan siswa dalam proses belajar dapat dilihat berdasarkan kemampuannya dalam menyelesaikan soal-soal pada materi yang telah disampaikan guru.

Pada penelitian sebelumnya yang dilakukan oleh Noviyanti \& Elya (2021) menunjukkan bahwa tahap-tahap kesulitan siswa dalam menyelesaikan operasi bilangan bulat adalah kesulitan fakta, kesulitan konsep, kesulitan operasi, dan kesulitan prinsip. Sedangkan faktor-faktor yang menjadi penyebab siswa kesulitan dalam menyelesaikan operasi bilangan bulat yaitu: 1) siswa kesulitan dalam menuliskan penjumlahan bilangan bulat dan menggambar pada garis bilangan, 2) siswa belum memahami konsep operasi pengurangan dan campuran bilangan bulat, 3) siswa kesulitan menentukan hasil dari pengurangan bilangan bulat, kurang teliti, tidak paham maksud soal, 4) siswa kesulitan membuat model matematika dari soal cerita, kesulitan menyatakan nilai operasi campuran dan belum menguasai materi operasi bilangan bulat. Selanjutnya pada penelitian kali ini, yang membedakan dari penelitian sebelumnya adalah materi yang akan diujikan dan subjek penelitian. Adapun yang akan dianalisis adalah kesulitan dalam menyelesaikan soal materi operasi bilangan cacah dengan subjek penelitian siswa kelas III SDIT Al-Husna.

Berdasar pada permasalahan yang dialami siswa SDIT Al-Husna dalam pembelajaran matematika tentang kesulitan yang dialami siswa dalam operasi bilangan cacah dan kesulitan pada proses belajarnya, maka dianggap penting dan perlu untuk dilakukan analisis sehingga peneliti tertarik untuk melalukan penelitian dengan judul "Analisis Kesulitan dalam Menyelesaikan Soal Materi Operasi Bilangan Cacah Siswa Sekolah Dasar”. Tujuan dari penelitian ini adalah menganalisis dan mendeskripsikan jenis kesulitan yang dialami siswa SDIT Al-Husna dalam menyelesaikan soal pada operasi bilangan cacah dalam bentuk soal cerita. 


\section{METODE}

Penelitian ini menggunakan metode deskriptif kualitatif. Metode deskriptif ini berarti termasuk dalam penelitian non-eksperimen tanpa memberikan treatment atau perlakuan. Menurut Sugiyono (2011), metode deskriptif merupakan metode yang digunakan untuk menganalisis atau menggambarkan suatu hasil penelitian namun tidak digunakan untuk membuat kesimpulan secara luas. Hasil dari analisis tersebut kemudian oleh peneliti dibuat menjadi sebuah narasi agar dapat menyajikan suatu gejala yang menjadi objek penelitian.

Sumber data dalam penelitian ini adalah peneliti itu sendiri. Sedangkan subjek dalam penelitian ini adalah siswa kelas III SDIT Al-Husna tahun pelajaran 2020/2021 sebanyak 7 siswa. Subjek penelitian ini dipilih sebagai sampel untuk menganalisis kesulitan siswa dalam menyelesaikan soal pada materi bilangan cacah. Alasan memilih 7 siswa ini sebagai subjek penelitian dikarenakan dilihat dari hasil ulangan harian pada mata pelajaran matematika masih di bawah KKM (Kriteria Ketuntasan Minimal) dan berdasarkan rekomendasi guru. Teknik pengumpulan data yang digunakan dalam penelitian ini berupa metode tes dan metode wawancara. Tujuan dilakukan wawancara untuk menggali informasi lebih dalam terkait kesulitan dalam menyelesaikan soal operasi bilangan cacah berdasarkan hasil jawaban pada tugas penyelesaian masalah sebelumnya. Instrumen yang digunakan dalam penelitian ini berupa soal cerita berbentuk essay sebanyak 5 (lima) butir soal. Berikut ini merupakan indikator soal yang digunakan dalam penelitian ini selengkapnya dalam Tabel 1.

Tabel 1. Indikator Soal Tes Operasi Hitung Penjumlahan, Pengurangan, Perkalian, dan Pembagian Bilangan Cacah

\begin{tabular}{|c|c|c|c|c|c|}
\hline $\begin{array}{c}\text { Standar } \\
\text { Kompetensi }\end{array}$ & $\begin{array}{l}\text { Kompetensi } \\
\text { Dasar }\end{array}$ & Indikator & $\begin{array}{l}\text { Nomor } \\
\text { Soal }\end{array}$ & $\begin{array}{l}\text { Tingkat } \\
\text { Kognitif }\end{array}$ & $\begin{array}{l}\text { Tingkat } \\
\text { Kesukaran }\end{array}$ \\
\hline \multirow{4}{*}{$\begin{array}{l}\text { 4. Melakukan } \\
\text { penjumlahan, } \\
\text { pengurangan, } \\
\text { perkalian, } \\
\text { dan } \\
\text { pembagian } \\
\text { dalam } \\
\text { menyelesaika } \\
\text { n masalah } \\
\text { pada operasi } \\
\text { bilangan } \\
\text { cacah }\end{array}$} & \multirow{4}{*}{$\begin{array}{l}4.1 \\
\text { Menyelesaikan } \\
\text { masalah yang } \\
\text { melibatkan } \\
\text { penggunaan } \\
\text { sifat-sifat } \\
\text { operasi hitung } \\
\text { pada bilangan } \\
\text { cacah }\end{array}$} & $\begin{array}{l}\text { 4.1.1 Menyelesaikan } \\
\text { soal cerita yang } \\
\text { berhubungan dengan } \\
\text { penjumlahan }\end{array}$ & 1,2 & C3 & Mudah \\
\hline & & $\begin{array}{l}\text { 4.1.2 Menyelesaikan } \\
\text { soal cerita yang } \\
\text { berhubungan dengan } \\
\text { pengurangan }\end{array}$ & 3 & C3 & Sedang \\
\hline & & $\begin{array}{l}\text { 4.1.3 Menyelesaikan } \\
\text { soal cerita yang } \\
\text { berhubungan dengan } \\
\text { perkalian }\end{array}$ & 4 & C3 & Sedang \\
\hline & & $\begin{array}{l}\text { 4.1.4 Menyelesaikan } \\
\text { soal cerita yang } \\
\text { berhubungan dengan } \\
\text { pembagian }\end{array}$ & 5 & C3 & Sulit \\
\hline
\end{tabular}

Sumber: Karlimah, Nur, \& Oktaviyani (2019)

Dalam proses analisis atau pengolahan data, penulis menggunakan teknik perhitungan rumus persentase, tujuannya untuk mengetahui persentase kesulitan siswa dalam menyelesaikan soal operasi bilangan cacah baik berupa penjumlahan, pengurangan, perkalian, dan pembagian. 
Adapun rumus yang digunakan dalam penelitian ini adalah

$$
P=\frac{F}{N} \times 100 \%
$$

Keterangan: $\quad P=$ persentase kesalahan jawaban

$F=$ frekuensi kesalahan jawaban

$N$ = banyaknya responden

Data selanjutnya diolah dan dihitung untuk mengetahui seberapa sulit siswa dalam menyelesaikan soal operasi hitung bilangan cacah berdasarkan kemampuan siswa dalam memahami maksud soal, memahami konsep yang seharusnya digunakan dalam menyelesaikan soal, memahami apa yang ditanyakan dalam soal dan bagaimana solusi penyelesaiannya. Tahap selanjutnya, penulis membuat interpretasi dan kesimpulan sehingga permasalahan yang diajukan dapat terjawab melalui hasil perhitungan secara statistik dan penafsiran. Untuk memperoleh keabsahan data, peneliti menggunakan teknik triangulasi. Sugiyono (2015) membedakan tiga macam triangulasi data, yaitu: triangulasi sumber, triangulasi teknik, dan triangulasi waktu, sedangkan dalam penelitian ini menggunakan triangulasi teknik.

\section{HASIL}

Berikut ini akan dijelaskan secara terperinci analisis hasil temuan dan kesulitan siswa sekolah dasar dalam menyelesaiakan soal essay berbentuk cerita pada materi operasi hitung bilangan cacah.

Tabel 2. Deskripsi Kesalahan Siswa dalam Menyelesaikan Soal Nomor 1

\begin{tabular}{clcc}
\hline $\begin{array}{c}\text { Nomor } \\
\text { Soal }\end{array}$ & Kesalahan & Frekuensi & Persentase \\
\hline 1 & Tidak dapat menggunakan operasi hitung matematika & 2 & $29 \%$ \\
& Tidak dapat memahami maksud soal dalam kalimat matematika & - & - \\
& Tidak dapat melakukan operasi hitung bilangan cacah & 5 & $71 \%$ \\
& Jumlah Siswa & 7 & \\
\hline
\end{tabular}

Sumber: diolah dari data penelitian, 2021

Dalam soal nomor 1, Tabel 2. menunjukkan persentase kesulitan siswa dalam menggunakan operasi hitung matematika sebesar $29 \%$, ditunjukkan pada deskripsi kesalahan tidak dapat menggunakan operasi hitung matematika. Persentase kesulitan dalam melakukan operasi hitung dalam menjumlahkan banyaknya butir telur (konteks dalam soal) sebesar 71\%, ditunjukkan dengan deskripsi kesalahan tidak dapat melakukan operasi hitung bilangan cacah. Sedangkan dalam soal nomor 2, 3, dan 4, semua deskripsi kesalahan terdapat siswa yang mengalaminya.

Dalam Tabel 3., deskripsi kesalahan tidak dapat menggunakan operasi hitung matematika dialami oleh 1 siswa, tidak dapat memahami maksud soal dalam kalimat matematika dialami oleh 3 siswa dan tidak dapat melakukan operasi hitung bilangan cacah dialami oleh 3 siswa.

Tabel 3. Deskripsi Kesalahan Siswa dalam Menyelesaikan Soal Nomor 2

\begin{tabular}{clcc}
\hline $\begin{array}{l}\text { Nomor } \\
\text { Soal }\end{array}$ & Kesalahan & Frekuensi & Persentase \\
\hline 2 & Tidak dapat menggunakan operasi hitung matematika & 1 & $14 \%$ \\
& Tidak dapat memahami maksud soal dalam kalimat matematika & 3 & $43 \%$ \\
& Tidak dapat melakukan operasi hitung bilangan cacah & 3 & $43 \%$ \\
& Jumlah Siswa & 7 & \\
\hline
\end{tabular}

Sumber: diolah dari data penelitian, 2021 
Dalam soal nomor 2, Tabel 3. menyajikan persentase kesulitan siswa dalam menggunakan operasi hitung matematika sebesar 14\%, persentase kesulitan siswa dalam mengubah soal ke dalam bentuk kalimat matematika sebesar $43 \%$, dan persentase kesulitan dalam melakukan operasi hitung dalam menjumlahkan posisi jarak tempuh sebesar $43 \%$.

Tabel 4. Deskripsi Kesalahan Siswa dalam Menyelesaikan Soal Nomor 3

\begin{tabular}{clcc}
\hline Nomor & Kesalahan & Frekuensi & Persentase \\
Soal & & & \\
\hline 3 & Tidak dapat menggunakan operasi hitung matematika & 4 & $57 \%$ \\
& Tidak dapat memahami maksud soal dalam kalimat matematika & 2 & $29 \%$ \\
& Tidak dapat melakukan operasi hitung bilangan cacah & 1 & $14 \%$ \\
& Jumlah Siswa & 7 & \\
\hline
\end{tabular}

Sumber: diolah dari data penelitian, 2021

Berdasarkan Tabel 4., dalam soal nomor 3, persentase kesulitan siswa dalam menggunakan operasi hitung matematika sebesar 57\%, persentase kesulitan siswa dalam mengubah soal ke dalam bentuk kalimat matematika sebesar 29\%, dan persentase kesulitan dalam melakukan menghitung selisih kenaikan suhu sebesar 14\%. Persentase kesulitan ini didasarkan pada deskripsi kelasahan, baik itu tidak dapat menggunakan operasi hitung matematika, tidak dapat memahami maksud soal dalam kalimat matematika, maupun tidak dapat melakukan operasi hitung bilangan cacah.

Tabel. 5 Deskripsi Kesalahan Siswa dalam Menyelesaikan Soal Nomor 4

\begin{tabular}{clcc}
\hline $\begin{array}{l}\text { Nomor } \\
\text { Soal }\end{array}$ & Kesalahan & Frekuensi & Persentase \\
\hline 4 & Tidak dapat menggunakan operasi hitung matematika & 2 & $29 \%$ \\
& Tidak dapat memahami maksud soal dalam kalimat matematika & 4 & $57 \%$ \\
& Tidak dapat melakukan operasi hitung bilangan cacah & 1 & $14 \%$ \\
& Jumlah Siswa & 7 & \\
\hline
\end{tabular}

Sumber: diolah dari data penelitian, 2021

Dalam soal nomor 4, berdasarkan deskripsi kesalahan yang tersaji dalam Tabel 5. persentase kesulitan siswa dalam menggunakan operasi hitung matematika sebesar $29 \%$, persentase kesulitan siswa dalam mengubah soal ke dalam bentuk kalimat matematika sebesar $57 \%$, dan persentase kesulitan dalam melakukan perkalian banyaknya karet sebesar $14 \%$.

Tabel 6. Deskripsi Kesalahan Siswa dalam Menyelesaikan Soal Nomor 5

\begin{tabular}{clcc}
\hline $\begin{array}{l}\text { Nomor } \\
\text { Soal }\end{array}$ & Kesalahan & Frekuensi & Persentase \\
\hline 5 & Tidak dapat menggunakan operasi hitung matematika & 4 & $57 \%$ \\
& Tidak dapat memahami maksud soal dalam kalimat matematika & 3 & $43 \%$ \\
& Tidak dapat melakukan operasi hitung bilangan cacah & - & - \\
& Jumlah Siswa & 7 & \\
\hline
\end{tabular}

Sumber: diolah dari data penelitian, 2021

Dari Tabel 6., dapat ditentukan persentase kesulitan siswa dalam menyelesaikan operasi hitung bilangan cacah untuk soal nomor 5. Dalam soal nomor 5, persentase kesulitan siswa dalam menggunakan operasi hitung matematika sebesar 57\%, persentase kesulitan siswa dalam mengubah soal ke dalam bentuk kalimat matematika sebesar $43 \%$. 
Dari data penelitian mengenai deskripsi persentase siswa (7 subjek yang diambil) yang mengalami kesulitan dalam menyelesaikan soal cerita operasi bilangan cacah, penulis kemudian menganalisis lebih lanjut. Penulis menemukan informasi bahwa kesulitan yang dialami siswa dalam mengerjakan soal cerita operasi bilangan cacah dapat dideskripsikan berdasarkan pada tahap mengerjakan soal tes kemudian ditindaklanjuti dengan wawancara.

Pada tahap mengerjakan soal tes: 1) Kesulitan dalam memahami maksud soal dan menuliskannya ke dalam kalimat matematika, 2) Tidak dapat menggunakan operasi hitung matematika (meliputi penjumlahan, pengurangan, perkalian, atau pembagian), 3) Tidak dapat menghitung dalam operasi baik penjumlahan, pengurangan, perkalian, maupun pembagian atau kesulitan dalam menyelesaikan soal berkaitan dengan materi operasi hitung bilangan cacah.

Kesulitan dalam memahami maksud soal dan menuliskannya ke dalam kalimat matematika, dapat diindikasikan dalam Gambar 1.

4. Rina membeli 7 kotak karet rambut. Satu kotak berisi 120 buah karet rambut. Berapakah banyaknya karet rambut yang dimiliki Rina?

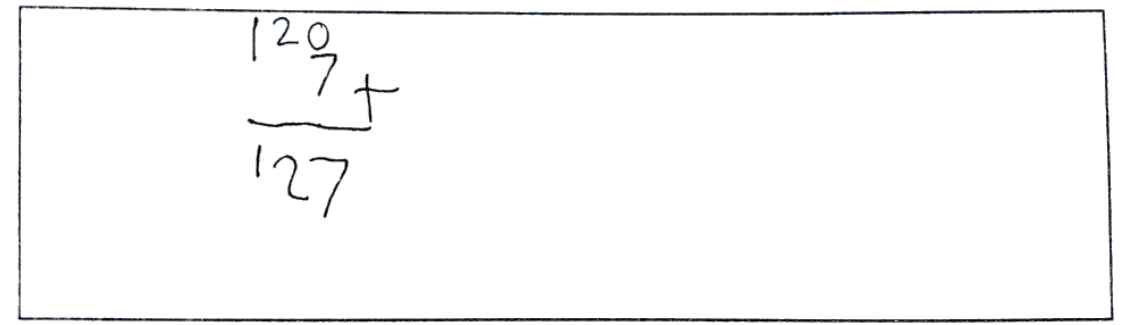

\section{Gambar 1. Kesulitan Siswa dalam Memahami Maksud Soal}

(S-1 pada Butir Soal Nomor 4)

Dari Gambar 1., terlihat bahwa siswa tidak memahami maksud soal sehingga salah dalam membuat kalimat matematika. Siswa kurang cermat dalam membaca soal dan kurang menangkapnya secara utuh, tidak memahami apa yang diketahui dan apa yang ditanyakan. Di dalam soal diketahui bahwa terdapat 7 kotak karet rambut dengan masing-masing kotak berisi 120 karet rambut. Seharusnya soal ini diselesaikan menggunakan konsep perkalian atau penjumlahan secara berulang. Jika ingin menggunakan konsep perkalian dengan penjumlahan berulang seharusnya siswa memiliki ide untuk menjumlahkannya sebanyak tujuh kali sesuai dengan apa yang diketahui dalam soal.

Begitu juga dialami siswa untuk butir soal nomor 3 diperlihatkan dalam Gambar 2.

3. Suhu sebuah balok es mula-mula $-5^{\circ} \mathrm{C}$. Setelah dipanaskan, es berubah menjadi air yang bersuhu $3^{\circ} \mathrm{C}$. Berapa kenaikan súhu es tersebut hingga menjadi air?

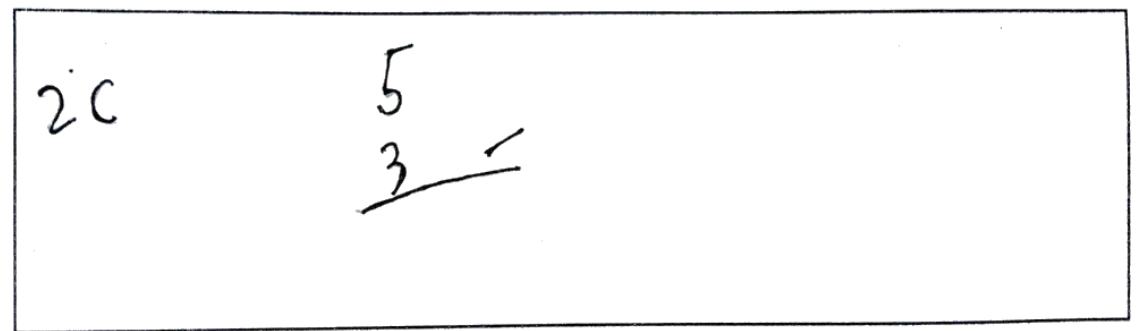

Gambar 2. Kesulitan Siswa dalam Memahami Maksud Soal (S-2 pada Butir Soal Nomor 3) 
Sama halnya seperti pada Gambar 1., terlihat bahwa siswa tidak memahami maksud soal sehingga salah dalam melakukan analisis ke dalam kalimat matematika. Gambar 2. menunjukkan kesalahan yang dialami siswa, seharusnya untuk menghitung kenaikan suhu dilakukan dengan menentukan selisihnya menggunakan operasi pengurangan yaitu $3-(-5)$. Akibatnya, siswa tidak dapat menjawab soal dengan sesuai seperti yang diperintahkan.

Selanjutnya, kesulitan yang dialami siswa dengan indikator tidak dapat menggunakan operasi hitung matematika (meliputi penjumlahan, pengurangan, perkalian, atau pembagian) terlihat dalam Gambar 3. maupun Gambar 4.

2. Sebuah kapal selam mula-mula berada sejauh $3 \mathrm{~m}$ dibawah permukaan laut, kemudian kapal menyelam kearah dasar laut $110 \mathrm{~m}$, kemudian kapal bergerak ke bawah lagi sejauh $20 \mathrm{~m}$. Hitunglah berapa m posisi terakhir kapal selam dari atas permukaan laut!

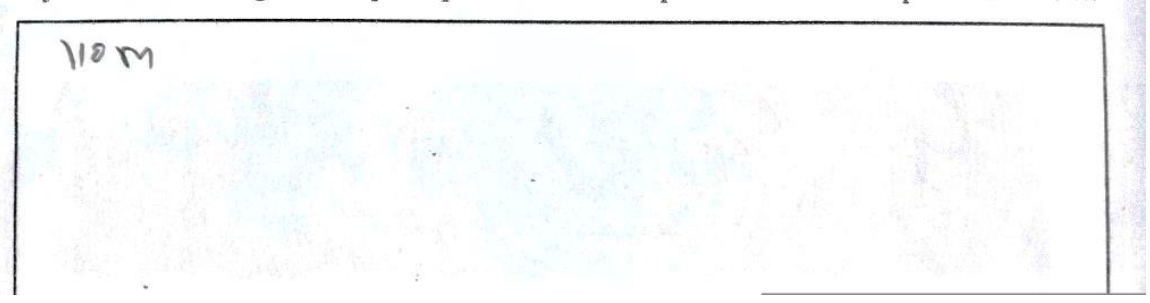

\title{
Gambar 3. Kesulitan Siswa dalam Menggunakan Operasi Hitung Penjumlahan (S-3 pada Soal Nomor 2)
}

\author{
5. Ibu Sri membeli 120 kue donat. Kue donat tersebut kemudian dibagikan kepada 15 \\ tetangga di sekitar rumahnya. Berapakah donat yang didapatkan oleh masing-masing \\ tetangga? \\ Gambar 4. Kesulitan Siswa dalam Menggunakan Operasi Hitung Perkalian \\ (S-3 pada Soal Nomor 5)
}

Dari Gambar 3. dan Gambar 4., terlihat bahwa siswa mengalami kesulitan dalam menjawab permintaan soal, siswa tidak mencermati soal secara utuh sehingga siswa langsung menuliskan jawaban tanpa adanya operasi hitung dan proses perhitungan. Jika siswa menjawab soal dengan benar tanpa ada coretan, kemungkinan mengerjakan perhitungan di lembar kertas lain. Namun karena jawaban siswa kurang tepat, besar kemungkinan siswa hanya menebak jawaban dengan melihat salah satu angka yang tertera dalam soal.

Siswa juga tidak dapat menghitung dalam operasi baik penjumlahan, pengurangan, perkalian, maupun pembagian atau kesulitan dalam menyelesaikan soal berkaitan dengan materi operasi hitung bilangan cacah. Kondisi ini terlihat dalam Gambar 5. 
1. Ibu membeli 450 butir telur untuk membuat kue pesanan, karena telur tersebut kurang maka ibu membeli lagi telur sebanyak 365 butir. Berapakah butir telur yang dimiliki ibu sekarang?

450
$\frac{365}{845}+$

\section{Gambar 5. Kesulitan Siswa dalam Melakukan Operasi Hitung Penjumlahan Bilangan (S-4 pada Soal Nomor 1)}

Terlihat bahwa dalam Gambar 5., hasil penjumlahan yang dilakukan oleh siswa kurang tepat, seharusnya hasil dari $450+845$ adalah 815 . Dalam prosedur penjumlahan bersusun, siswa sudah menempatkan posisi bilangan dengan benar, hanya saja pada saat perhitungan puluhan, siswa melakukan kesalahan karena seharusnya $5+6=11$. Lalu pada bilangan ratusan dan satuan siswa menyelesaikannya dengan tepat. Jika pun semisal siswa menjawab puluhannya 14 , seharusnya menggunakan penjumlahan dengan teknik menyimpan. Dari 7 siswa yang dijadikan subjek, mereka menggunakan strategi penyelesaian yang sama yaitu penjumlahan bersususun dengan teknik menyimpan. Tiga bilangan yang akan dihitung ditempatkan secara bersusun, bilangan yang akan dikurangi berada di posisi atas dan bilangan pengurangnya berada di posisi bawah. Kemudian digit bilangan yang paling kanan dijumlahkan, dilanjut dengan bilangan digit kedua dari kanan dan seterusnya. Jika misal hasil penjumlahan bilangan di sebelah kanan terdiri dari dua angka, maka tempatkan digit kedua dan simpan bilangan digit pertama di atas bilangan sebelah kanan kedua begitupun seterusnya. Gambar 6. merupakan ilustrasi dari proses penjumlahan dengan teknik menyimpan.

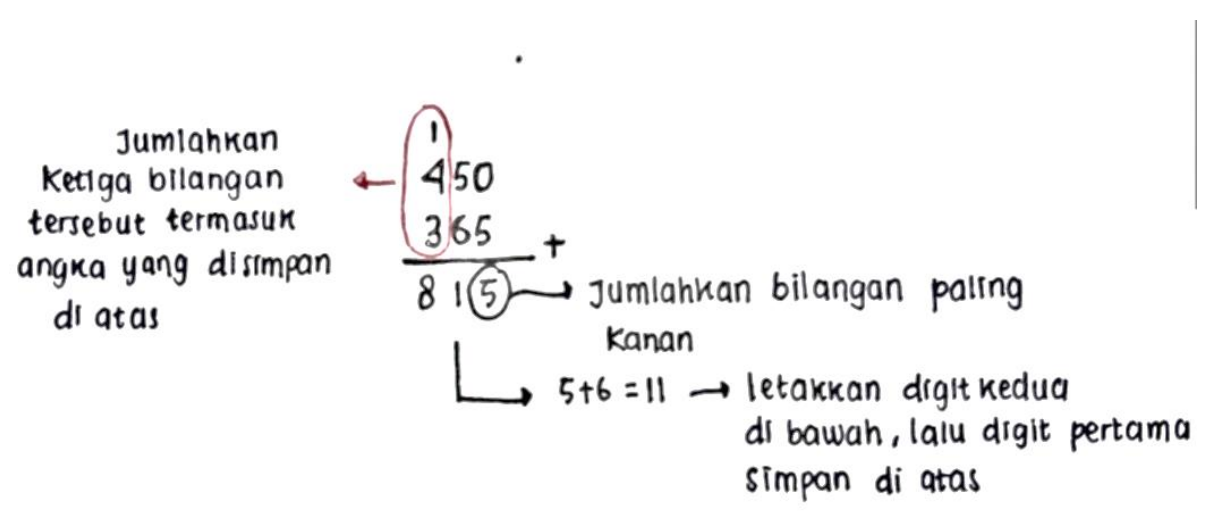

\section{Gambar 6. Ilustrasi Penjumlahan Tiga Bilangan dengan Teknik Menyimpan}

Selanjutnya fakta yang diperoleh melalui jawaban tertulis diperdalam dengan wawancara. Pada tahap wawancara menunjukkan juga adanya kesulitan yang dialami siswa. Hal ini juga menguatkan temuan dalam lembar jawab tes sebelumnya. Sedangkan tujuan dilakukannya wawancara agar bisa mengetahui lebih dalam penyebab kesulitan siswa dalam menyelesaikan soal cerita operasi bilangan cacah.

Subjek wawancara adalah siswa yang diberikan tes. 
Berikut hasil wawancara siswa dalam menyelesaikan soal cerita operasi bilangan cacah Peneliti : "Ibu sudah mengoreksi hasil jawaban kalian dan rata-rata jawaban kalian hanya benar 1 atau 2 soal saja selebihnya jawaban yang lain salah."

Siswa : (diam)

Peneliti : "Sekarang Ibu mau tanya kepada kalian, mengapa jawaban kalian banyak yang salah? apakah ada kesulitan dalam mengerjakannya?"

Siswa : "Iya Bu, saya tidak mengerti maksud soal yang diberikan." (jawab seluruh siswa serempak)

Peneliti : "Apakah semua soalnya sulit?"

Siswa : "Iya Bu, kita kesulitan mengerjakan soal yang berbentuk cerita, tidak paham menggunakan operasi penjumlahan, pengurangan, perkalian, atau pembagian."

Peneliti : "Baik. Sekarang kita coba bahas bareng-bareng ya. Misal nomor 2, ibu coba bacakan ya soalnya, "Sebuah kapal selam mula-mula berada sejauh $3 \mathrm{~m}$ di bawah permukaan laut, kemudian kapal menyelam ke arah dasar laut $110 \mathrm{~m}$, kemudian kapal bergerak ke bawah lagi sejauh $20 \mathrm{~m}$. Hitunglah berapa m posisi terakhir kapal selam dari atas permukaan air?". Nah, jadi kan kapal selam berada sejauh 3 m ya, lalu menyelam lagi sejauh 110 m dan untuk ketiga kali menyelam lagi sejauh 20 m. Jadi jika menyelam terus kira-kira ditambah atau dikurang?"

Siswa : (diam masih mencerna)

Peneliti : "Jadi bentuknya adalah penjumlahan yaitu penjumlahan dari $3+110+20=$ 133."

Siswa : "Oh iya Bu." (mulai mengangguk tanda mengerti).

Berdasarkan hasil wawancara di atas dapat disimpulkan penyebab kesulitan siswa yang paling utama adalah memahami maksud soal dan pemahaman konsep operasi hitung.

Selanjutnya penulis juga melakukan wawancara pada salah satu siswa yang menjawab soal dengan salah dalam kasus yang berbeda.

Berikut hasil wawancara antara penulis dengan subjek (S-4)

Peneliti : "Mengapa jawaban nomor 1 kamu salah?"

Subjek : (diam)

Peneliti : "Formula yang kamu gunakan sudah benar menggunakan teknik penjumlahan bersusun, apakah kamu masih belum bisa melakukan operasi hitung penjumlahan?"

Subjek :Iya bu, saya masih kesulitan dalam menghitung."

Berdasarkan hasil wawancara di atas dapat disimpulkan bahwa siswa masih kesulitan dalam berhitung. Hal ini menguatkan temuan sebelumnya berdasarkan hasil jawaban tertulis siswa.

\section{PEMBAHASAN}

Berdasarkan hasil analisis pada lembar jawaban siswa, secara umum kesulitan yang ditemukan dalam menyelesaikan soal berbentuk cerita: 1) kesulitan dalam menggunakan operasi hitung matematika; 2) kesulitan dalam memahami soal yang dimaksud dan kesulitan dalam menerjemahkannya ke dalam kalimat matematika; 3) kesulitan dalam menyelesaikan soal berkaitan dengan materi operasi hitung bilangan cacah (meliputi penjumlahan, pengurangan, perkalian, dan pembagian).

Berdasarkan hasil jawaban siswa, banyak ditemukan siswa yang tidak memahami maksud soal sehingga menyebabkan siswa tidak dapat menyelesaikan soal. Hal ini ditemukan bukan saja hanya saat siswa diberikan soal tes, namun penulis sering menjumpainya saat pembelajaran berlangsung. Sebelum 
mengerjakan soal biasanya siswa sering menanyakan maksud soal kepada guru dan memintanya untuk dijelaskan. Untuk memahami maksud soal, siswa terlebih dahulu perlu melakukan analisis sehingga diperoleh informasi untuk selanjutnya dijadikan dasar dalam mengambil keputusan saat menyelesaikan soal. Kesulitan siswa dalam menyelesaikan soal cerita disebabkan karena siswa kurang cermat dalam membaca dan memahami kalimat demi kalimat, tidak mengerti apa yang diketahui dan ditanyakan dalam soal. Kesulitan dalam memahami maksud soal ke dalam kalimat matematika ini dialami oleh hampir seluruh siswa yang mengerjakan soal tes.

Berdasarkan analisis jawaban siswa, banyak ditemukan solusi penyelesaian tanpa menggunakan operasi hitung matematika. Hal ini mungkin terjadi karena siswa hanya menebak jawaban tanpa adanya proses berpikir relasional instrumental yang baik. Penyebab kesulitan siswa dalam menyelesaikan soal cerita, dipicu oleh kurangnya pemahaman konsep matematis dan tidak memahami maksud soal seperti yang sebelumnya dijelaskan. Misalnya, operasi hitung penjumlahan adalah penyelesaian menjumlah pada bilangan dalam menemukan hasil penjumlahan dari dua bilangan atau lebih (Arnidha, 2015; Imelda et. al., 2014). Bilangan cacah terdiri dari bilangan asli dan bilangan nol (Karlimah et. al., 2019).

Pada kasus lain, berdasarkan hasil analisis jawaban siswa, ditemukan beberapa siswa masih belum bisa dalam mengoperasikan bilangan. Hal ini terlihat dari hasil akhir jawaban siswa yang salah. Penyebab siswa kesulitan dalam proses berhitung ini bisa diakibatkan oleh beberapa faktor, salah satunya faktor internal atau faktor yang timbul dari dalam diri siswa. Biasanya siswa tidak dilatih untuk berhitung sehingga daya ingat siswa terhadap materi-materi yang telah diajarkan oleh guru, begitu saja mudah dilupakan oleh siswa.

Tidak dapat dipungkiri juga, kurang terampilnya guru dalam mengemas pembelajaran yang menarik, kreatif, dan inovatif sesuai dengan perkembangan zaman, maka akan berpengaruh terhadap motivasi dan minat belajar matematika siswa (Kurniawan, Wahyuningsih, \& Pangadongan, 2019). Pada saat memberikan tes dalam bentuk soal cerita ternyata siswa lebih sulit dalam mengerjakannya dibanding dengan soal dalam bentuk matematika secara langsung, hal ini pada faktanya memang benar adanya. Berdasarkan hasil wawancara juga menguatkan temuan dalam analisis jawaban tertulis siswa. dapat disimpulkan penyebab kesulitan siswa yang paling utama adalah memahami maksud soal dan pemahaman konsep operasi hitung.

Pada saat pembelajaran di hari-hari biasanya ketika siswa dihadapkan dengan soal dalam bentuk cerita, mereka selalu menanyakan kepada guru maksud dari soal yang ditanyakan. Mereka merasa sulit menentukan operasi perhitungan apa yang digunakan untuk menjawab soal.

Dari kesalahan-kesalahan siswa dalam mengerjakan soal pada saat tes dan hasil wawancara diuraikan penyebab kesulitan siswa sebagai berikut:

1. Siswa tidak terbiasa mengerjakan soal dalam bentuk cerita. Mereka lebih mudah mengerjakan soal dalam bentuk bilangan matematika secara langsung. Kesulitan utama mereka dalam menyelesaikan soal cerita adalah karena mereka tidak bisa menerjemahkan soal yang dimaksud ke dalam kalimat matematika, siswa tidak mencermati soal secara utuh. Hal ini disebabkan karena kurangnya kemampuan literasi.

2. Siswa belum memahami secara pasti materi bilangan cacah

3. Siswa belum pandai dalam melakukan operasi hitung terutama perkalian dan pembagian. Meski dalam setiap pembelajaran siswa selalu dilatih untuk menghafal perkalian, namun masih banyak siswa yang belum hafal perkalian walaupun perkalian 1 sampai 5. Ketika guru melakukan tes perkalian, yang paling diingat siswa adalah perkalian 1 dan 5. Saat ditanya pada perkalian 2-4 siswa diam sejenak untuk berpikir dan menghitung menggunakan jari dan masih menggunakan konsep penjumlahan berulang sehingga menghabiskan waktu yang cukup lama untuk menjawab soal.

4. Dilihat dari lembar jawaban, siswa kebanyakan hanya menuliskan hasil akhir tanpa ada penjabaran dalam bentuk kalimat untuk mempejelas maksud dari hasil jawaban yang diperoleh. Hal ini 
menunjukkan bahwa siswa tidak terampil dalam berbahasa atau komunikasi matematis dalam bentuk tulisan.

Berkaitan dengan kesulitan yang dialami siswa, maka penulis memberikan beberapa alternatif yaitu:

1. Menciptakan inovasi pembelajaran yang lebih kreatif, sehingga dapat meningkatkan minat dan motivasi belajar siswa.

2. Melatih dan membiasakan siswa dalam berhitung baik dengan memberikan soal maupun tes hafalan. Memahami kesulitan-kesulitan yang dialami siswa sampai mereka benar-benar paham terhadap operasi perhitungan karena konsep perhitungan bilangan ini merupakan dasar untuk mempelajari matematika yang lebih kompleks di jenjang selanjutnya.

3. Kesulitan dalam memahami soal berbentuk cerita dapat diatasi dengan memberikan kalimat soal yang lebih sederhana, tidak bertele-tele sehingga mudah dimengerti oleh siswa. Selain itu kemampuan literasi matematik juga perlu ditingkatkan.

\section{SIMPULAN}

Berdasar pada hasil penelitian, secara umum kesulitan yang ditemukan dalam menyelesaikan soal berbentuk cerita yaitu: 1) kesulitan dalam menggunakan operasi hitung matematika; 2) kesulitan dalam memahami soal yang dimakud dan kesulitan dalam menerjemahkannya ke dalam kalimat matematika; 3 ) kesulitan dalam menyelesaikan soal berkaitan dengan materi operasi hitung bilangan cacah (penjumlahan, pengurangan, perkalian, dan pembagian). Hal ini sebagaimana dari hasil analisis diketahui bahwa persentase tertinggi kesulitan siswa dalam melakukan operasi hitung mencapai $71 \%$. Untuk mengatasi kesulitan tersebut, maka peneliti memberikan beberapa alternatif yaitu: 1) menciptakan inovasi pembelajaran yang lebih kreatif, sehingga dapat meningkatan minat dan motivasi belajar siswa; 2) melatih dan membiasakan siswa dalam berhitung baik dengan memberikan soal maupun tes hafalan; 3) kesulitan dalam memahami soal cerita dapat diatasi dengan memberikan kalimat soal yang lebih sederhana sehingga mudah dimengerti oleh siswa.

\section{DAFTAR RUJUKAN}

Arnidha, Y. (2015). Analisis Kesalahan Siswa dalam Menyelesaikan Soal Operasi Hitung Bilangan Cacah. JURNAL E-DuMath, 1(1).

Depdiknas. (2006). Kurikulum Tingkat Satuan Pendidikan (KTSP).

Djamarah, Bahri Syaiful. 2015. Psikologi Belajar. Jakarta: Rineka Cipta.

Haryadi, R., \& Nurmaningsih, N. (2019). Analisis Kesalahan Mahasiswa dalam Menyelesaikan Soal Persamaan Garis Lurus. Jurnal Elemen, 5(1), 1-11.

Imawati, T., \& Dharma, U. S. (2016). Diagnosis Kesulitan Belajar Matematika Pada Materi Luas dan Keliling Lingkaran di Kelas VIII E SMP Negeri 2 Jatinom. Universitas Sanata Dharma: Yogyakarta.

Imelda, M., Yusmin, E., \& Suratman, D. (2014). Profil kesalahan siswa dalam menyelesaikan soal operasi hitung campuran bilangan bulat di SMP. Jurnal Pendidikan Dan Pembelajaran, 3(2), 1-13.

Karlimah, K., Nur, L., \& Oktaviyani, H. (2019). Pemahaman Konsep Operasi Hitung Penjumlahan Bilangan Cacah Siswa Sekolah Dasar. Premiere Educandum: Jurnal Pendidikan Dasar Dan Pembelajaran, 9(2), $123-129$.

Kompri. (2015). Manajemen Pendidikan. Bandung: Alfabeta

Kurniawan, D., Wahyuningsih, T., \& Pangadongan, F.V.(2019). Pelatihan Kepada Guru SD untuk Mengajarkan Konsep Luas Bidang Datar dengan Menggunakan MEQIP (Mathematic Eduation Quality Improvement. International Journal of Community Service Learning, 3(2), 56-62. Retrieved from: 
https://repository.unmul.ac.id/bitstream/handle/123456789/4466/17812-25888-1-

SM.pdf?sequence $=1 \&$ is Allowed $=\mathrm{y}$

Mandasari, N., \& Rosalina, E. (2021). Analisis Kesulitan Siswa dalam Menyelesaikan Soal Operasi Bilangan Bulat di Sekolah Dasar. Jurnal Basicedu, 5(3), 1139-1148.

Rubai, R., Yunianta, T. N. H., \& Wahyudi, W. (2015). Strategi Guru Matematika dalam Mengatasi Kesulitan Belajar Bagi Siswa Kelas X Smk Negeri 2 Salatiga. Satya Widya, 31(1), 32-42.

Sugiyono. (2011). Metode Penelitian Kualitatif dan R\&D. Yogyakarta: Alfabeta.

Sugiyono. (2015). Metode Penelitian Kuantitatif, Kualitatif, dan $R \&$ D. Yogyakarta: Alfabeta.

Utami, L. (2016). Analisis Kesulitan Siswa SMP Kelas VII dalam Menyelesaikan Soal Operasi Hitung Bilangan dan Solusi Pemecahannya. In Konferensi Nasional Penelitian Matematika dan Pembelajarannya (KNPMP I) (pp. 246-259). Surakarta: Universitas Muhammadiyah Surakarta.

Widyastuti, N. S., \& Pujiastuti, P. (2014). Pengaruh Pendidikan Matematika Realistik Indonesia (PMRI) Terhadap Pemahaman Konsep dan Berpikir Logis Siswa. Jurnal Prima Edukasia, 2(2), 183-193. 
306 Nengsih, \& Pujiastuti

JKPM (Jurnal Kajian Pendidikan Matematika) Vol.6, No.2 (2021) 